\title{
ANALISIS PERBANDINGAN KINERJA KARYAWAN DI PT. PERUSAHAAN LISTRIK NEGARA (PLN) (PERSERO) WILAYAH NUSA TENGGARA BARAT (STUDI KASUS PADA RAYON AMPENAN DAN RAYON CAKRANEGARA)
}

\author{
Marlina Fujiana Lestari' ${ }^{1}$ H. Zainal Abidin ${ }^{2}$, Rusminah $^{3}$ \\ ${ }^{1}$ Fakultas Ekonomi Dan Bisnis Universitas Mataram, marlina fujianalestari@yahoo.com \\ ${ }^{2}$ Fakultas Ekonomi Dan Bisnis Universitas Mataram, zainal.abidin@unram.ac.id \\ ${ }^{3}$ Fakultas Ekonomi Dan Bisnis Universitas Mataram, rusminag@unram.ac.id
}

\begin{abstract}
The research aim is to find out is there any differences which significant between rayon employees performance at ampenan and rayon employees at cakranegara, this is quantitative comparative research data collecting technique done by interview and documentation population in this research are all rayon employess at ampenan and cakranegara, with the number are 40 person, which consist of 20 of person in rayon ampenan and the same number in rayon cakra yet, the number of population is less than 100 person thus, all employees are made as samples. Analysis data conducted trough t test, and Research result shows that there is no significant different between rayon employees performance at ampenan and rayon employees at cakra in which the significant value is 0.554 or $p>0.05$, the average value on rayon ampenan is 109.7 and rayon cakra is 108.9 , the employees performance have the same ability which more than expectation and extraordinary achievement and they expert in their job thus their performance received should be keeping up trough an exercise to create their quality and technical ability.
\end{abstract}

\section{Keyword: performance, rayon employees of ampenan and cakranegara}

\begin{abstract}
ABSTRAK
Penelitian ini bertujuan untuk mengetahui ada tidaknya perbedaan yang signifikan antara kinerja karyawan Rayon Ampenan dan Rayon Cakranegara. Penelitian ini merupakan penelitian kuantitatif komparatif. Teknik pengumpulan data dengan cara wawancara dan dokumentasi. Populasi dalam penelitian ini adalah seluruh karyawan yang ada di Rayon Ampenan dan Rayon Cakranegara berjumlah 40 orang, yang terdiri dari 20 orang di Rayon Ampenan dan 20 Orang di Rayon Cakranegara. Karena jumlah populasi tersebut kurang dari 100 maka seluruh karyawan tersebut dijadikan sampel total atau sensus. Dan analisis data dilakukan dengan uji beda (uji t) yaitu independent sample t-test. Hasil Penelitian ini menunjukkan bahwa tidak ada perbedaaan yang signifikan antara kinerja karyawan Rayon Ampenan dan Rayon Cakranegara dimana nilai probabilita/sig. $=0,544$ atau $\mathrm{p}>0,05$. Nilai rata-rata pada Rayon Ampenan mencapai angka sebesar 109,7, dan Rayon Cakranegara mencapai angka yaitu sebesar 108,9. Kinerja karyawan sama-sama memiliki kemampuan yang melampaui harapan dan pencapaian luar biasa, dan menguasai bidang tugasnya sesuai posisi jabatan masing-masing. Sehingga prestasi kerja yang telah diperoleh harus di pertahankan dan terus meningkatkan kinerja karyawannya. Untuk dapat meningkatkan kinerja perlu juga dilakukan pengembangan karyawan secara terus menerus dengan cara pelatihan untuk meningkatkan kualitas SDM dan kemampuan teknis.
\end{abstract}

Kata kunci: Kinerja, Karyawan Rayon Ampenan dan Rayon Cakranegara 


\section{PENDAHULUAN}

Sumber daya manusia merupakan salah satu faktor produksi dalam perusahaan yang sangat berperan penting dalam menentukan perkembangan untuk mencapai tujuan perusahaan. Untuk mencapai tujuan perusahaan diperlukan karyawan yang sesuai dengan persyaratan dalam perusahaan dan harus mampu menjalankan tugas-tugas yang telah ditentukan oleh perusahaan. Dengan demikian sumber daya manusia yang telaten dan handal sangat berperan dalam memajukan perusahaan, karena sumber daya manusia berfungsi sebagai langkah awal penggerak kinerja perusahaan.

Menurut Mangkunegara (2015:67) kinerja atau prestasi kerja adalah hasil kerja secara kualitas dan kuantitas yang dicapai oleh pegawai dalam melaksanakan tugasnya sesuai dengan tanggung jawab yang diberikan kepadanya. Kemudian Dessler (2009) berpendapat bahwa kinerja (prestasi kerja) karyawan adalah prestasi aktual karyawan dibandingkan dengan prestasi yang diharapkan dari karyawan. Prestasi kerja yang diharapkan adalah prestasi standar yang disusun sebagai acuan sehingga dapat melihat kinerja karyawan sesuai posisinya yang dibandingkan dengan standar yang dibuat. Selain itu dapat juga dilihat kinerja dari karyawan tersebut terhadap karyawan lainnya.

Setiap organisasi harus mampu memberikan pelayanan yang baik untuk selalu meningkatkan kinerja yang tinggi, salah satunya yang diselenggarakan pemerintah melalui BUMN (Badan Usaha Milik Negara). Salah satu BUMN yang bergerak di sektor hajat hidup masyarakat yaitu PT. PLN (Persero). PT. PLN (Persero) sebagai sebuah BUMN yang memiliki kegiatan usaha berorientasi pada pelayanan masyarakat, sangat dituntut untuk selalu menjaga dan meningkatkan kinerja karyawannya, agar senantiasa memberikan layanan terbaik untuk konsumennya. Dalam memberikan pelayanan, PT. PLN (Persero) memiliki unit terkecil yaitu tingkat Rayon, yang merupakan unit yang langsung menghadapi dan melayani kebutuhan listrik masyarakat.

PT. PLN (Persero) Wilayah Nusa Tenggara Barat memiliki konsumen atau pelanggan dalam jumlah yang banyak dan tersebar di Wilayah Nusa Tenggara Barat tersebut khususnya di wilayah Pulau Lombok, dan untuk menjaga efektivitas dan intensitas pelayanannya, maka wilayah kerja atau wilayah pelayanan (service area) terbagi dalam bentuk Rayon, dan di Pulau Lombok yang merupakan PT. PLN (Persero) Area Mataram memiliki 6 (enam) Rayon. Dari ke 6 (enam) Rayon tersebut, penulis memilih objek penelitian pada 2 (dua) Rayon, yaitu Rayon Ampenan dan Rayon Cakranegara, dengan dasar pertimbangan bahwa cakupan ke-2 (kedua) Rayon tersebut berada di wilayah kerja perkotaan, dan kebutuhan listrik di perkotaan lebih dari sekedar kebutuhan dasar. Tenaga listrik sudah menjadi salah satu faktor produksi dalam bidang industri dan jasa, termasuk pula kebutuhan utama disektor pelayanan publik atau kantor pemerintahan, oleh karena semua peralatan pendukung aktifitas masyarakat sudah menggunakan serba elektronik yang membutuhkan daya listrik. Permasalahannya adalah manakala pada Rayon Ampenan dan Rayon Cakranegara tersebut pelayanan kelitrikannya tidak optimal, maka akan berdampak luas terhadap berbagai sektor kegiatan masyarakat yaitu terganggunya aktivitas kegiatan pemerintahan dalam pelayanan publik, terganggunya aktivitas sektor perdagangan dan jasa, terganggunya kegiatan industri, terganggunya kegiatan rumah tangga dan lain sebagainya.

Berdasarkan uraian di atas, maka kinerja pegawai pada setiap Rayon dapat menjadi jaminan maju tidaknya suatu organisasi, salah satu aspek penilaian terhadap kinerja karyawan adalah ditinjau dari tingkat kehadirannya dalam bekerja. Dalam indikator kinerja karyawan menurut Dessler (2010) kehadiran merupakan salah satu poin yang mencerminkan kinerja karyawan. Mudiartha (2001:93) menyatakan rata-rata 
absensi sebesar 2-3 persen perbulan masih bisa dinyatakan baik dan absensi lebih dari 3 persen menggambarkan kondisi disiplin kerja yang tidak baik dalam organisasi. Data absensi karyawan Rayon Ampenan dan Rayon Cakranegara memiliki tingkat absensi kurang dari 3 persen perbulannya atau dalam rata-rata pertahun dihitung berdasarkan data sakit, cuti besar, cuti tahunan dan izin maka ini menunjukkan bahwa tidak ada indikasi permasalahan yang terjadi di dalam perusahaan tersebut khususnya mengenai kehadiran karyawan dalam bekerja. Akan tetapi bila dilihat dari angka tingkat kehadiran pada Rayon Cakranegara lebih tinggi dibandingkan dengan Rayon Ampenan. Perbedaan tingkat kehadiran masuk bekerja berdasarkan rekapitulasi kehadiran karyawan pada ke 2 (dua) Rayon tersebut, antara lain disebabkan adanya karyawan yang berhalangan seperti sakit dan izin tidak masuk bekerja. Adapun karyawan yang tidak masuk bekerja juga disebabkan karena bertugas keluar daerah, hal itu dapat dilihat berdasarkan data Surat Perintah Perjalanan Dinas (SPPD), dimana SPPD yang dikeluarkan pada Rayon Ampenan relatif lebih tinggi dibandingkan dengan Rayon Cakranegara, dengan rata-rata SPPD kurang dari $2 \%$ di tahun 2013, dan kemudian menunjukkan angka lebih dari 2\% di tahun berikutnya. Sedangkan di Rayon Cakranegara dari tahun 2013-2017, rata-rata SPPD yang dikeluarkan kurang dari 2\%. Adapun yang menyebabkan SPPD lebih banyak dikeluarkan di Rayon Ampenan karena karyawan mengikuti rapat kerja, seminar, pelatihan, konsultasi ke PLN pusat dan cek kesehatan untuk keperluan jabatan yang di dudukinya, dan sebagainya. Selain itu, yang menyebabkan adanya perbedaan tingkat kehadiran masuk bekerja di Rayon Ampenan juga disebabkan adanya cuti tahunan dan cuti besar, meskipun hal itu adalah merupakan hak karyawan tetapi dapat berpengaruh terhadap kehadiran dalam bekerja.

Selain itu PT. PLN (Persero) Wilayah NTB dalam meningkatkan kinerjanya dapat ditinjau dari seberapa jauh karyawan dapat menyelesaikan target kerja yang telah ditentukan perusahaan terutama pada tingkat masing-masing Rayon yang langsung memberikan pelayanan listrik terhadap pelanggan. Dapat dilihat dari Key Performance Indicators (KPI) yang telah ditetapkan pada masing-masing Rayon tersebut dimana KPI merupakan indikator kunci atau indikator utama kinerja pegawai, dengan sistem pengukuran kinerjanya berdasarkan KPI yang telah ditetapkan. Berdasarkan data KPI Rayon Ampenan tahun 2017, pencapaiannya sebesar 97,74 belum mencapai target yang telah ditentukan yaitu sebesar 100 . Hal ini disebabkan karena adanya beberapa sub indikator yang belum dapat dicapai secara maksimal sesuai dengan target yang telah ditetapkan, antara lain yaitu indikator Perspektif Pelanggan khususnya sub indikator SAIDI dan SAIFI.

Dalam Surat Edaran Direksi PT. PLN (Persero) NO.002/E/DIR/2013, tingkat kehandalan distribusi tenaga listrik, diukur dengan SAIDI (System Average Interruption Duration Index) yaitu suatu sistem perhitungan indeks rata-rata lama padam per pelanggan dalam pertahun, yang dihitung dalam durasi menit lama padam untuk setiap pelanggan (menit/pelanggan/tahun). Indikator SAIDI ini ditargetkan agar diupayakan secara maksimal untuk ditekan atau diminimalkan supaya pemadaman listrik tidak berlangsung dalam durasi waktu yang lama. Kemudian SAIFI (System Average Interruption Frequency Index) yaitu suatu sistem perhitungan indeks rata-rata jumlah frekuensi gangguan listrik untuk setiap pelanggan pertahun yang dihitung berdasarkan berapa kali terjadinya gangguan listrik untuk setiap pelanggan pertahun (kali/pelanggan/tahun). Indikator SAIFI ini ditargetkan agar diupayakan secara maksimal untuk ditekan atau diminimalkan supaya frekuensi gangguan listrik tidak sering terjadi pada setiap pelanggan pertahun. Adapun yang menyebabkan tidak tercapainya SAIDI dan SAIFI tersebut karena terjadinya Outage, keadaan dimana suatu komponen tidak dapat 
berfungsi sebagaimana mestinya diakibatkan karena beberapa peristiwa yang berhubungan dengan komponen tersebut seperti tipe dan kondisi peralatan distribusi, konfigurasi jaringan distribusi, dan dalam tahap memperbaiki jaringan distribusi dan lainnya.

Selain itu, target yang masih belum dapat tercapai adalah pada indikator Perspektif Efektivitas Produk dan Proses yang sub indikatornya adalah adanya Gangguan Penyulang, yang merupakan salah satu indikator agar efektivitas produk layanan kelistrikan kepada pelanggan dapat terlaksana dengan efisien dengan menekan terjadinya Gangguan Penyulang. Gangguan Penyulang tersebut belum mencapai target disebabkan antara lain karena adanya gangguan cuaca, gangguan pepohonan disekitar jaringan listrik, terjadinya insiden isolator pecah dan sebagainya. Berkenaan dengan permasalahan di atas, dalam beberapa kasus pemadaman listrik, pada kenyataannya menjadi sumber keluhan dan kekecewaan masyarakat. Berbagai dampak dirasakan oleh masyarakat dari adanya pemadaman listrik tersebut, antara lain yaitu macetnya jalan raya ketika rambu lalu lintas mati, terjadinya gangguan dalam proses produksi pada industri rumah tangga, Sektor Pelayanan Publik di Kantor Pemerintahan menjadi terganggu, dan sebagainya.

Kemudian untuk Key Performance Indicators (KPI) pada Rayon Cakranegara pencapaiannya sebesar 97,31 belum mencapai target yang ditetapkan yaitu sebesar 100 . Artinya bahwa pencapaian pada Rayon Cakranegara sebesar 97,31 lebih rendah dari yang dicapai oleh Rayon Ampenan yaitu sebesar 97,74. Hal itu disebabkan karena belum tercapainya target pada indikator Perspektif Pelanggan dengan sub indikator berupa Rasio Elektrifikasi, SAIDI dan SAIFI. Berkaitan dengan persoalan indikator Rasio Elektrifikasi pada Rayon Cakranegara yang belum mencapai target yang ditetapkan, dimana Rasio Elektrifikasi ini harus menunjukkan peningkatan dalam setiap tahunnya. Maka perlu diketahui bahwa wilayah kerja Rayon Cakranegara meliputi wilayah Lombok Barat. Pada beberapa kawasan di wilayah Lombok Barat memiliki kondisi geografis berupa perbukitan dan penduduknya terpencar-pencar sehingga sampai di wilayah yang terpencil dan sulit dijangkau. Dalam kondisi demikian, maka PT. PLN (Persero) lebih memprioritaskan pada masyarakat yang berada dalam pemukiman dan penduduk dalam jumlah banyak dan terkonsentrasi. Implikasi dari kondisi tersebut, maka tidak dapat terpenuhinya target Rasio Elektrifikasi, yaitu perbandingan antara jumlah penduduk dan total penduduk yang telah mendapatkan layanan kelistrikan. Pada sisi lain, berkaitan dengan indikator Perspektif Efektifitas Produk dan Proses dengan sub indikator penjualan Tenaga Listrik Non Subsidi pada pelanggan rumah tangga. Berdasarkan indikator / sub indikator tersebut, Rayon Cakranegara masih belum dapat mencapai target yang telah ditetapkan.

Berdasarkan latar belakang di atas, maka peneliti merasa tertarik untuk mengangkat topik dengan judul "Analisis Perbandingan Kinerja Karyawan Di PT. Perusahaan Listrik Negara (PLN) (Persero) Wilayah Nusa Tenggara Barat (Studi Kasus Pada Rayon Ampenan dan Rayon Cakranegara)”.

\section{Perumusan Masalah}

Berdasarkan latar belakang yang telah diuraikan di atas, maka yang menjadi pokok permasalahan yang akan dibahas dalam penelitian ini yaitu "Apakah ada perbedaan yang signifikan antara kinerja karyawan di Rayon Ampenan dan Rayon Cakranegara?". 


\section{Tujuan Penelitian}

Tujuan dalam penelitian ini adalah:

"Untuk mengetahui dan menganalisis ada tidaknya perbedaan yang signifikan antara kinerja karyawan di Rayon Ampenan dan Rayon Cakranegara".

\section{Manfaat Penelitian}

Adapun manfaat penelitian ini adalah sebagai berikut:

1. Manfaat Akademis

Sebagai bahan untuk menyusun skripsi dalam rangka memenuhi syarat untuk mencapai kebulatan studi program strata satu (S-1) pada Fakultas Ekonomi dan Bisnis Universitas Mataram.

2. Manfaat Teoritis

Menambah pengetahuan dan wawasan bagi peneliti tentang perbedaan kinerja karyawan yang ada di Rayon Ampenan dan Rayon Cakranegara dan menghubungkan teori yang didapat dalam perkuliahan dengan kenyataannya, serta dapat memperdalam pengetahuan penulis dalam bidang manajemen sumber daya manusia.

3. Manfaat Kebijakan

Sebagai informasi bagi perusahaan mengenai perbedaan kinerja karyawannya yang ada di Rayon Ampenan dan Rayon Cakranegara, kemudian menjadi bahan masukan untuk mencari solusi dan merumuskan kebijakan dalam hal meningkatkan kualitas kinerja karyawan.

\section{KAJIAN PUSTAKA DAN PENGEMBANGAN HIPOTESIS}

\section{Pengertian Kinerja}

Rivai (2008:14) mengungkapkan bahwa, kinerja adalah hasil atau tingkat keberhasilan seseorang secara keseluruhan selama periode tertentu di dalam melaksanakan tugas dibandingkan dengan berbagai kemungkinan, seperti standar hasil kerja, target atau sasaran atau kriteria yang telah ditentukan terlebih dahulu dan telah disepakati bersama. Kemudian menurut Moeheriono (2014:96) Kinerja merupakan hasil kerja yang dapat dicapai oleh seseorang atau sekelompok orang dalam suatu organisasi baik secara kuantitatif maupun kualitatif, sesuai dengan kewenangan dan tugas tanggung jawab masing-masing, dalam upaya mencapai tujuan organisasi bersangkutan secara legal, tidak melanggar hukum dan sesuai dengan moral maupun etika.

\section{Pengertian Key Performance Indicators (KPI)}

Dalam setiap proses pengukuran kinerja dibutuhkan suatu ukuran untuk mengetahui tingkat keberhasilan atau capaian dari kinerja perusahaan tersebut. Salah satu ukuran yang digunakan dalam proses pengukuran kinerja adalah Indikator Kinerja Utama/Key Performance Indicators (KPI). Indikator Kinerja Utama / Key Performance Indicators (KPI) merupakan suatu indikator yang digunakan untuk mengetahui seberapa jauh strategi yang telah dilakukan oleh perusahaan sesuai dengan visi dan misi perusahaan (Moeheriono, 2012:1). Indikator Kinerja Utama / Key Performance Indicators (KPI) ini juga memiliki peran lain selain sebagai ukuran keberhasilan dalam suatu perusahaan (Moeheriono, 2012:47), antara lain yaitu:

1) Sebagai indikator bagi karyawan untuk mengetahui dimana area karyawan tersebut harus bekerja dan menghasilkan output sesuai dengan target yang telah ditentukan. 
2) Sebagai alat komunikasi atasan dengan bawahan ataupun perusahaan ke seluruh lini organisasi.

3) Sebagai media yang secara eksplisit menyatakan kemampuan proses yang harus dicapai, sehingga target perusahaan juga tercapai.

Berdasarkan pengertian di atas, Maka Key Performance Indicators (KPI) adalah nilai terukur yang menunjukkan seberapa efektif sebuah perusahaan mencapai tujuan bisnis utamanya. Organisasi menggunakan KPI diberbagai tingkat tinggi dapat berfokus pada keseluruhan kinerja perusahaan. KPI merupakan indikator yang memberikan informasi sejauh mana karyawan telah berhasil mewujudkan target kerja yang telah ditetapkan.

\section{Pengukuran Kinerja Organisasi BUMN}

Kriteria Penilaian Kinerja Unggul Badan Usaha Milik Negara (KPKU BUMN) merupakan sistem evaluasi kinerja yang digunakan oleh BUMN.

Berdasarkan pendekatan KPKU, terdapat 5 (lima) perspektif pengukuran kinerja usaha yang telah diberlakukan kementerian BUMN dalam surat keputusan nomor S08/S.MBU/2013 mengenai Pedoman Penentuan Key Performance Indicators (KPI) Pada Badan Usaha Milik Negara antara lain:

1. Perspektif Efektivitas Produk dan Proses.

Perspektif produk dan proses memfokuskan pada hasil-hasil kinerja produk dan operasional utama dari perusahaan, yang bertujuan memeragakan mutu dan nilai produk dan jasa yang menimbulkan kepuasan dan keterikatan pelanggan.

Perspektif ini menekankan pada ukuran-ukuran kinerja produk yang berfungsi sebagai indikator dari sisi pandangan pelanggan dan keputusan-keputusan pelanggan yang relatif terhadap interaksi dan hubungan masa depan.

2. Perspektif Pelanggan

Perspektif ini memfokuskan pada hasil-hasil kinerja, fokus pada pelanggan dari perusahaan, yang bertujuan menunjukkan sebaik apa perusahaan telah memuaskan pelanggan dan keterikatannya dalam hubungan jangka panjang. Perspektif ini juga fokus pada seluruh data yang relevan untuk menentukan dan membantu memprediksi kinerja perusahaan dari sisi pandangan pelanggan.

Perspektif ini menekankan hasil-hasil fokus pada pelanggan yang melebihi pengukuran kepuasan, karena keterikatan dan hubungan pelanggan merupakan indikator dan ukuran yang lebih baik terhadap keberhasilan masa depan di pasar dan indikator dan ukuran kesinambungan perusahaan.

3. Perspektif Keuangan dan Pasar.

Perspektif keuangan dan pasar memfokuskan hasil-hasil finansial dan pasar utama dari perusahaan, yang bertujuan menunjukkan kesinambungan finansial dan pencapaian pasar.

Ukuran-ukuran yang dapat diidentifikasi adalah ukuran-ukuran yang biasanya ditelusuri oleh pemimpin senior secara terus-menerus untuk menilai kinerja finansial dan visibilitas perusahaan. Pengukuran kinerja pasar bisa meliputi ukuran pertumbuhan bisnis, produk dan pasar baru yang dimasuki, atau persentase pemasukan yang berasal dari produk baru.

4. Perspektif Fokus Tenaga Kerja (SDM)

Perspektif fokus tenaga kerja memfokuskan hasil-hasil kinerja perusahaan dalam aspek fokus pada tenaga kerja atau sumberdaya manusia, yang tujuannya adalah untuk mengetahui seberapa baik perusahaan dalam menciptakan dan memelihara: (1) 
lingkungan kerja yang produktif, peduli, dan membangun keterikatan (engaging); dan (2) lingkungan pembelajaran untuk semua tenaga kerja.

5. Perspektif Kepemimpinan, Tata Kelola dan Tanggung Jawab Kemasyarakatan Perspektif kepemimpinan, tata kelola dan tanggung jawab kemasyarakatan memfokuskan hasil-hasil utama perusahaan di bidang kepemimpinan senior dan tata kelola, yang ditujukan untuk menunjukkan perusahaan yang mapan secara keuangan dan beretika yang memenuhi tanggung jawab sosialnya dan mendukung komunitas utamanya.

Hasil yang dilaporkan harus meliputi penaatan lingkungan, hukum, dan peraturan; hasil-hasil dari audit pengawasan oleh pemerintah atau lembaga pendanaan; dan pencapaian-pencapaian yang layak untuk dicatat dalam bidang ini. Hasil-hasil juga harus meliputi kontribusi perusahaan terhadap kesejahteraan sosial dan manfaat serta dukungan kepada komunitas utama.

\section{Kerangka Konseptual dan Pengembangan Hipotesis Kerangka Konseptual}

Kerangka konseptual bertujuan untuk mengemukakan secara umum mengenai objek penelitian yang dilakukan dalam kerangka dari variabel yang akan diteliti.

Dalam penelitian ini akan dibandingkan hasil kerja antara karyawan yang ada di Rayon Ampenan dan Rayon Cakranegara dan kerangka konseptualnya sebagai berikut:

\begin{tabular}{|c|c|c|}
\hline Kinerja & Perbandingan & \multirow{2}{*}{$\begin{array}{c}\text { Kinerja } \\
\text { Karyawan di Rayon } \\
\text { Cakranegara }\end{array}$} \\
\hline $\begin{array}{c}\text { Karyawan di Rayon } \\
\text { Ampenan }\end{array}$ & & \\
\hline 1. Perspektif & $\downarrow$ & \multirow{10}{*}{$\begin{array}{l}\text { 1. Perspektif } \\
\text { Pelanggan } \\
\text { 2. Perspektif } \\
\text { Efektifitas dan } \\
\text { Proses } \\
\text { 3. Perspektif SDM } \\
\text { 4. Perspektif } \\
\text { Keuangan dan Pasar } \\
\text { 5. Perspektif } \\
\text { Kepemimpinan }\end{array}$} \\
\hline Pelanggan & & \\
\hline 2. Perspektif & Ada Perbedaan & \\
\hline Efektifitas dan & & \\
\hline Proses & & \\
\hline 3. Perspektif SDM & Tidak Ada & \\
\hline 4. Perspektif & Perbedaan & \\
\hline Keuangan dan Pasar & & \\
\hline 5. Perspektif & & \\
\hline Kepemimpinan & & \\
\hline
\end{tabular}

Gambar 2.1: Kerangka Konseptual

\section{Pengembangan Hipotesis}

Dessler (2009) berpendapat bahwa kinerja (prestasi kerja) karyawan adalah prestasi aktual karyawan dibandingkan dengan prestasi yang diharapkan dari karyawan. Prestasi kerja yang diharapkan adalah prestasi standar yang disusun sebagai acuan sehingga dapat melihat kinerja karyawan sesuai posisinya yang dibandingkan dengan standar yang dibuat. Selain itu dapat juga dilihat kinerja dari karyawan tersebut terhadap karyawan lainnya.

Mengenai penelitian perbedaan kinerja antara karyawan Rayon Ampenan dan Rayon Cakranegara. Hingga saat ini belum ada penelitian yang menghasilkan 
perbandingan kinerja antara karyawan Rayon Ampenan dan Rayon Cakranegara. Namun mengenai perbandingan kinerja karyawan dapat ditunjukkan oleh masing-masing perusahaan tempat karyawan bekerja.

Penelitian yang dilakukan oleh Vinny Damayanti dan Marliana (2007) kinerja karyawan di restoran yang menerapkan ISO 9001-2000 dengan yang tidak menerapkan ISO 9001-2000 menunjukkan tidak adanya perbedaan yang signifikan. Demikian pula pada penelitian Fauziah (2016) yang membandingkan kinerja pegawai di Kantor Camat Tambusai dan Kantor Camat Rambah menunjukkan tidak adanya perbedaan kinerja pegawai yang signifikan antara kedua kantor camat tersebut berdasarkan perhitungan nilai rata-rata TCR dengan nilai skor 78.3 di Kantor Camat Tambusai 79.8 dan di Kantor Camat Rambah dengan kategori yang sama-sama baik.

Berdasarkan uraian di atas maka hipotesis yang ditetapkan dalam penelitian ini adalah sebagai berikut:

"Tidak terdapat perbedaan kinerja yang signifikan antara karyawan yang ada di Rayon Ampenan dan Rayon Cakranegara".

\section{METODE PENELITIAN}

\section{Jenis Penelitian}

Di dalam melakukan penelitian, penulis menggunakan jenis komparatif (perbandingan). Menurut Sugiyono (2010:57) jenis komparatif adalah jenis penelitian yang membandingkan keberadaan satu variabel atau lebih pada dua atau lebih sampel yang berbeda, atau pada waktu yang berbeda. Untuk membantu menganalisis data dan fakta yang diperoleh, maka digunakan metode analisa kuantitatif dengan rumus statistik yang gunanya untuk menguji teori dan hipotesis untuk menemukan apakah ada perbedaan variabel pada sampel data yang diperoleh dalam penelitian ini.

\section{Populasi dan Sampel Populasi}

Populasi adalah wilayah generalisasi yang terdiri atas obyek atau subyek yang mempunyai kualitas dan karaktristik tertentu yang ditetapkan oleh peneliti untuk dipelajari dan kemudian ditarik kesimpulannya (Sugiyono, 2012:115). Populasi pada penelitian ini adalah seluruh karyawan yang ada di Rayon Ampenan dan Rayon Cakranegara yaitu sebanyak 40 karyawan, yang terdiri dari 20 karyawan di Rayon Ampenan dan 20 karyawan di Rayon Cakranegara.

\section{Sampel}

Menurut (Sugiyono, 2017) sampel adalah bagian dari jumlah dan karaktristik yang dimiliki oleh populasi tersebut. Menurut Arikunto (2006:134) jika jumlah populasi kurang dari 100, maka untuk dijadikan sampel diambil seluruhnya. Penelitian yang menggunakan seluruh anggota populasi disebut sampel total (total sampling) atau sensus. Menurut Sugiyono (2010:142) sensus atau sampling jenuh adalah teknik penentuan sampel bila semua anggota populasi dijadikan sampel penelitian. Sampel dalam penelitian ini adalah seluruh populasi yang ada pada Rayon Ampenan dan Rayon Cakranegara sebanyak 40 orang yang terdiri dari 20 orang karyawan di Rayon Ampenan dan 20 orang karyawan di Rayon Cakranegara di tahun 2017.

Untuk lebih jelasnya komposisi sampel total atau sensus dalam penelitian ini dapat dilihat pada Tabel 3.1. di bawah ini: 
Tabel 3.1. Sampel Total atau Sensus

\begin{tabular}{|l|c|c|}
\hline \multirow{2}{*}{ Jabatan } & \multicolumn{2}{c|}{ Karyawan } \\
\cline { 2 - 3 } & $\begin{array}{c}\text { Rayon } \\
\text { Ampenan }\end{array}$ & $\begin{array}{c}\text { Rayon } \\
\text { Cakranegara }\end{array}$ \\
\hline Supervisor Transaksi Energi Listrik (TEL) & 1 & 1 \\
\hline Staff & 6 & 6 \\
\hline Supervisor Teknik & 1 & 1 \\
\hline Staff & 5 & 7 \\
\hline Supervisor Pelayanan Pelanggan dan Administrasi & 1 & 1 \\
\hline Staff & 6 & 20 \\
\hline Jumlah Sampel & 20 & \\
\hline Total Sampel & \multicolumn{2}{|c}{40} \\
\hline
\end{tabular}

Sumber: PT. PLN (Persero) Wilayah NTB, Tahun 2018.

\section{Definisi Konseptual dan Operasional Variabel \\ Definisi Konseptual}

Rivai (2008:14) mengungkapkan bahwa, kinerja adalah hasil atau tingkat keberhasilan seseorang secara keseluruhan selama periode tertentu di dalam melaksanakan tugas dibandingkan dengan berbagai kemungkinan, seperti standar hasil kerja, target atau sasaran atau kriteria yang telah ditentukan terlebih dahulu dan telah disepakati bersama.

Maka indikator-indikator kinerja yang digunakan adalah indikator yang sesuai dengan yang diterapkan oleh perusahaan PT. PLN (Persero) serta dengan definisi yang telah diberlakukan kementerian BUMN dalam surat keputusan nomor S-08/S.MBU/2013 mengenai Pedoman Penentuan Key Performance Indicators (KPI) Pada Badan Usaha Milik Negara antara lain:

1. Perspektif Pelanggan

Perspektif ini memfokuskan pada hasil-hasil kinerja, fokus pada pelanggan dari perusahaan, yang bertujuan menunjukkan sebaik apa perusahaan telah memuaskan pelanggan dan keterikatannya dalam hubungan jangka panjang.

2. Perspektif Efektivitas Produk dan Proses.

Perspektif produk dan proses memfokuskan pada hasil-hasil kinerja produk dan operasional utama dari perusahaan, yang bertujuan memeragakan mutu dan nilai produk dan jasa yang menimbulkan kepuasan dan keterikatan pelanggan.

3. Perspektif Fokus Tenaga Kerja (SDM)

Perspektif fokus tenaga kerja memfokuskan hasil-hasil kinerja perusahaan dalam aspek fokus pada tenaga kerja atau sumberdaya manusia, yang tujuannya adalah untuk mengetahui seberapa baik perusahaan dalam menciptakan dan memelihara: (1) lingkungan kerja yang produktif, peduli, dan membangun keterikatan (engaging); dan (2) lingkungan pembelajaran untuk semua tenaga kerja.

4. Perspektif Keuangan dan Pasar

Perspektif keuangan dan pasar memfokuskan hasil-hasil finansial dan pasar utama dari perusahaan, yang bertujuan menunjukkan kesinambungan finansial dan pencapaian pasar.

5. Perspektif Kepemimpinan, Tata Kelola dan Tanggung Jawab Kemasyarakatan Perspektif kepemimpinan, tata kelola dan tanggung jawab kemasyarakatan memfokuskan hasil-hasil utama perusahaan di bidang kepemimpinan senior dan tata kelola, yang ditujukan untuk menunjukkan perusahaan yang mapan secara keuangan 
dan beretika yang memenuhi tanggung jawab sosialnya dan mendukung komunitas utamanya.

\section{Definisi Operasional Variabel}

Definisi operasional merupakan petunjuk tentang bagaimana suatu variabel diukur. Kinerja karyawan adalah persepsi pimpinan terhadap hasil kerja secara keseluruhan, baik pada karyawan Rayon Ampenan maupun karyawan Rayon Cakranegara selama periode tertentu yang merupakan tanggung jawab sebagai pimpinan dalam menilai prestasi kerja dengan menggunakan Key Performance Indicators (KPI) yaitu 5 perspektif antara lain:

1. Perspektif Pelanggan

2. Perspektif Efektivitas Produk dan Proses

3. Perspektif Sumber Daya Manusia

4. Perspektif Keuangan dan Pasar

5. Perspektif Kepemimpinan

Berikut di bawah ini definisi operasional variabel dari 5 perspektif yang diterapkan PT. PLN (Persero) Wilayah NTB yaitu:

1. Perspektif Pelanggan adalah persepsi pimpinan terhadap kinerja karyawan pada Rayon Ampenan dan Rayon Cakranegara dari segi perspektif pelanggan yaitu kepuasan pelanggan terhadap pelayanan untuk terpenuhinya kebutuhan daya listrik. Indikator Perspektif Pelanggan terdiri dari 2 (dua) Sub Indikator, yaitu:

a. Rasio Elektrifikasi

b. Kehandalan Jaringan, yaitu: SAIDI dan SAIFI

2. Perspektif Efektifitas Produk dan Proses adalah persepsi pimpinan terhadap kinerja pegawai pada Rayon Ampenan dan Rayon Cakranegara dari segi perspektif terhadap produk dan layanan kelistrikan kepada pelanggan dan proses layanan agar terlaksanan secara efektif dan efisien.

Ada 4 (empat) Sub Indikator dari Perspektif Efektivitas Produk dan Proses yaitu:

a. Penjualan Tenaga Listrik Non Subsidi

b. Susut Jaringan

c. Gangguan Penyulang

d. Rasio Kerusakan Trafo Distribusi

3. Perspektif Sumber Daya Manusia adalah persepsi pimpinan terhadap karyawan pada Rayon Ampenan dan Rayon Cakranegara, yaitu sejauh mana sumber daya manusia yang ada, memiliki daya tanggap dan responsif terhadap permasalahan pelanggan.

4. Perspektif Keuangan dan Pasar adalah persepsi pimpinan terhadap karyawan pada Rayon Ampenan dan Rayon Cakranegara yang memfokuskan hasil-hasil finansial dan pasar utama dari perusahaan, yang bertujuan menunjukkan kesinambungan finansial dan pencapaian pasar.

Adapun Indikator Perspektif Keuangan dan Pasar, terdiri dari:

a. Biaya Pokok Penyediaan (BPP)

b. Efektifitas biaya pemeliharaan

c. Pencapaian investasi

d. Perputaran material non bahan bakar

e. Harga jual rata-rata

f. Pengendalian piutang

5. Perspektif Kepemimpinan adalah persepsi pimpinan terhadap karyawan pada Rayon Ampenan dan Rayon Cakranegara mengenai kepatuhan dan ketentuan yang berlaku pada perusahaan yang berkaitan dengan pelaksanaan tugas. Adapun sub indikator perspektif kepemimpinan yaitu: 
a. Implementasi K2

b. Tindak lanjut temuan auditor

c. Kepatuhan terhadap keselamatan ketenagalistrikan dan lingkungan hidup.

\section{Penggunaan Rumus dalam Perhitungan KPI}

Untuk mengukur kinerja karyawan dengan menggunakan instrument KPI digunakan rumus untuk menghitung tingkat pencapaian kinerja karyawan. Rumus ini digunakan dalam perhitungan hasil kerja pada populasi Rayon Ampenan dan Rayon Cakranegara. Adapun rumus tersebut diuraikan sebagai berikut:

1. $\uparrow$ KPI Polaritas Positif, yaitu semakin besar realisasi, maka pencapaian semakin baik. Dengan rumus:

$$
\text { Skor }=100+\left[\frac{(\mathrm{R}-\mathrm{T})}{\mathrm{T}}\right] \times 100 \%
$$

2. $\downarrow$ KPI Polaritas Negatif, yaitu semakin kecil realisasi, maka pencapaian semakin baik.

Dengan rumus:

$$
\begin{aligned}
& \text { Skor }=100+\left[\frac{(\mathrm{T}-\mathrm{R})}{\mathrm{T}}\right] \times 100 \% \\
& \mathrm{R}=\text { Realisasi } \\
& \mathrm{T}=\text { Target } \\
& \text { Nilai }=\text { Bobot }+\% \times \text { Skor }
\end{aligned}
$$

\section{Teknik Pengumpulan Data}

Teknik pengumpulan data di dalam penelitian ini adalah:

1. Wawancara

2. Dokumentasi

\section{Prosedur Analisis Data \\ Uji Asumsi}

Karena penelitian ini menggunakan data kuantitatif maka penulis menganalisis menggunakan statistik. Rumus yang digunakan adalah rumus independent sample t-test atau uji t. Ada beberapa persyaratan yang harus dipenuhi sebelum uji-t dilakukan (Husaini dan Purnomo, 2008: 140). Uji prasyarat dilakukan untuk mengetahui data yang dianalisis terdistribusi secara normal dan homogen. Uji prasyarat terdiri dari uji normalitas dan uji homogenitas (Rahayu, 2005).

Persyaratannya adalah:

1. Uji Normalitas

Tujuan dari uji normalitas data adalah untuk mengetahui distribusi data dalam variabel kinerja yang akan digunakan dalam penelitian ini. Pengujian normalitas hasil temuan data pada penelitian ini menggunakan bantuan SPSS 23.0 yang kemudian ditarik kesimpulan dengan memeriksa uji statistik Kolmogorov-Smirnov. Data dikatakan berdistribusi normal jika analisis mempunyai nilai Asymp.sig. (2-tailed) > 0,05 (Triton, 2006: 172)

2. Uji Homogenitas

Uji homogenitas digunakan untuk mengetahui apakah dua atau lebih kelompok data sampel berasal dari populasi yang memiliki variansi yang homogen (sama) atau tidak. Teknik yang akan digunakan untuk menguji homogenitas adalah program SPSS 23.0 for windows: test of homogeneity of variances dengan uji levene statistic. Data dikatakan homogen jika nilai sig $>0,05$ (Triton, 2006: 173). 


\section{Uji Hipotesis}

\section{Independent Sample t-test}

Teknik analisis yang digunakan untuk uji hipotesis penelitian yaitu uji beda atau uji t. Uji t yang digunakan yaitu uji independent sample t-test. Sebelum dilakukan analisis independent sample t-test. terlebih dahulu data harus memenuhi syarat awal, syarat tersebut antara lain:

1) Data berbentuk interval atau rasio

2) Data sampel berasal dari populasi yang berdistribusi normal

3) Variansi antara dua sampel yang dibandingkan tidak berbeda secara signifikan (homogen)

4) Data berasal dari dua sampel yang berbeda

5) Jumlah sampel dibawah 30 atau dengan kata lain $n 1$ dan $n 2$ adalah $<30$, syarat 30 ini bukan akumulasi $\mathrm{n}$ dari 2 kelompok sampel melainkan $\mathrm{n}$ untuk masing-masing kelompok sampel. Pengujian hipotesis yang dilakukan dengan analisis Independent sample t-test pada program SPSS, pengambilan keputusannya dilakukan dengan membandingkan nilai thitung dengan tebel dengan ketentuan:

a. Jika thitung $<\mathrm{t}_{\text {tabel }}$ maka $\mathrm{H}_{0}$ diterima dan $\mathrm{H}_{\mathrm{a}}$ ditolak

b. Jika thitung $>$ tabel maka $\mathrm{H}_{0}$ ditolak dan $\mathrm{H}_{\mathrm{a}}$ diterima

Selain itu pengambilan keputusan juga dapat dilihat dari taraf signifikan p (Sig (2tailed)). Jika $\mathrm{p}>0,05$ maka $\mathrm{H}_{0}$ diterima dan jika $\mathrm{p}<0,05$ maka $\mathrm{H}_{0}$ ditolak (Triton, 2006: 175).

Sehingga untuk memudahkan perhitungan, maka seluruh perhitungan dilakukan dengan bantuan komputer program SPSS 23.0 for windows. Tingkat signifikansi yang digunakan adalah $\alpha=5 \%$.

Menentukan Hipotesis yaitu:

$\mathrm{H}_{0}$ : Diterima artinya, tidak terdapat perbedaan yang signifikan antara kinerja karyawan di Rayon Ampenan dan Rayon Cakranegara

$\mathrm{H}_{\mathrm{a}}$ : Diterima artinya, ada perbedaan yang signifikan antara kinerja karyawan di Rayon Ampenan dan Rayon Cakranegara

\section{HASIL PENELITIAN DAN PEMBAHASAN}

\section{Tugas dan Fungsi Rayon}

Sesuai surat Keputusan Direksi PT. PLN (Persero) nomor 556.K/DIR/2014, fungsi dan tugas pokok rayon adalah mengelola operasi dan pemeliharaan sistem kelistrikan, serta mengelola niaga dan pelayanan pelanggan sesuai dengan kewenangannya dalam rangka meningkatkan pelayanan ketenagalistrikan secara efisien dan efektif dengan mutu dan keandalan untuk mencapai target kinerja unit.

\section{Data Penelitian}

Deskripsi Data

Dalam penentuan sasaran dan target kerja yang tertuang dalam analisis pekerjaan (job description) pegawai Rayon Ampenan dan Rayon Cakranegara menggunakan Cascading KPI yakni dari atasan ke para bawahan, sebagaimana Manajer Area menurunkan pekerjaannya ke Asmen (Asisten Manajer), dan Manajer Rayon, sedangkan untuk Asmen dan Manajer Rayon menurunkannya ke Supervisor, dan untuk yang terakhir Supervisor menurunkan pekerjaannya ke para Staff. 
Jadi dari uraian diatas dapat diketahui bahwa pelaksanaan analisis pekerjaan yang ada di Rayon Ampenan dan Rayon Cakranegara ini diturunkan secara Top Down dan bersifat turunan yakni dari atasan ke-bawahan.

Dalam menyusun KPI terdapat beberapa prinsip atau kriteria SMART yang harus dipenuhi yaitu:

1. Specific, artinya sasaran kinerja/unjuk kerja pegawai seharusnya terfokus pada arah dari pekerjaan serta usaha yang diperlukan untuk mencapai tujuan Perseroan.

2. Measurable, artinya sasaran kinerja/unjuk kerja pegawai harus bisa diukur baik secara kuantitatif (misalnya penurunan biaya sebesar 5\%), maupun secara kualitatif (misalnya peningkatan kepuasan pelanggan dalam hal kecepatan penyambungan sebesar 3\%).

3. Achievable, artinya sasaran kinerja/unjuk kerja harus bisa dicapai sehingga memerlukan proses diskusi, kesepakatan, dan pemahaman baik oleh atasan langsung maupun oleh pegawai.

4. Realistic, artinya sasaran kinerja/unjuk kerja pegawai harus dapat dicapai dalam konteks yang sesuai dengan keterampilan dan kemampuan pegawai, serta mendapatkan dukungan sumber daya yang tersedia.

5. Time Bound, artinya sasaran kinerja/unjuk kerja pegawai harus mempunyai target waktu sehingga dapat membantu pegawai untuk memprioritaskan rencana kerja dan menggunakan sumber daya dengan efektif.

\section{Kriteria Hasil Penilaian Kinerja}

Tabel 4.1. Tingkat Klasifikasi / Penggolongan Kompetensi Karyawan

\begin{tabular}{|c|c|c|c|c|c|}
\hline No & $\begin{array}{c}\text { Level } \\
\text { Performance }\end{array}$ & Target Kinerja & \multicolumn{2}{|c|}{ Kategori Pencapaian } & $\begin{array}{c}\text { Tingkat } \\
\text { Kompetensi }\end{array}$ \\
\hline 1 & $401-500$ & $>110 \%$ & OS & $\begin{array}{c}\text { Pencapaian Luar Biasa } \\
\text { (Outstanding) }\end{array}$ & Kompetensi 1 \\
\hline 2 & $301-400$ & $101 \%-110 \%$ & ER & $\begin{array}{c}\text { Melampaui Harapan } \\
\text { Exceeds Requirements) }\end{array}$ & Kompetensi 2 \\
\hline 3 & $201-300$ & $91 \%-100 \%$ & MR & $\begin{array}{c}\text { Memenuhi Persyaratan } \\
\text { (Meet Requirements) }\end{array}$ & Kompetensi 3 \\
\hline 4 & $101-200$ & $75 \%-90 \%$ & NI & $\begin{array}{c}\text { Perlu Pengembangan } \\
\text { (Need Improvement) }\end{array}$ & Kompetensi 4 \\
\hline 5 & $0-100$ & $\leq 75 \%$ & MG & $\begin{array}{c}\text { Pencapaian Minimum } \\
\text { (Marginal) }\end{array}$ & Kompetensi 5 \\
\hline
\end{tabular}

Sumber: PT. PLN (Persero) Wilayah NTB, Tahun 2018.

\section{Pencapaian Kinerja Karyawan Berdasarkan Posisi Penugasan}

Berdasarkan penelitian terhadap sampel sebanyak 40 karyawan pada Rayon Ampenan dan Rayon Cakranegara yang masing-masing terdiri dari 20 orang, maka dapat diketahui tingkat pencapaian kinerja masing-masing karyawan berdasarkan posisi penugasan dan uraian tugas masing-masing (Job Description) sesuai dengan perspektif indikator KPI. Pencapaian kinerja karyawan berdasarkan penugasan karyawan, maka adapun rata-rata kriteria prestasi karyawan dapat dilihat pada tabel 4.2 dibawah ini: 
Tabel 4.2 Penilaian Prestasi Kerja Karyawan Rayon Ampenan dan Rayon Cakranegara Tahun 2017.

\begin{tabular}{|l|c|c|c|c|c|}
\hline \multicolumn{1}{|c|}{ Variabel } & $\begin{array}{c}\text { 401-500 OS } \\
\text { (Kompetensi 1) }\end{array}$ & $\begin{array}{c}\text { 301-400 ER } \\
\text { (Kompetensi 2) }\end{array}$ & $\begin{array}{c}\text { 201-300 MR } \\
\text { (Kompetensi 3) }\end{array}$ & $\begin{array}{c}\text { 101-200 NI } \\
\text { (Kompetensi 4) }\end{array}$ & $\begin{array}{c}\text { 0-100 MG } \\
\text { (Kompetensi 5) }\end{array}$ \\
\hline $\begin{array}{l}\text { Rayon } \\
\text { Ampenan }\end{array}$ & 10 & 10 & - & - & - \\
\hline $\begin{array}{l}\text { Rayon } \\
\text { Cakranegara }\end{array}$ & 8 & 12 & - & - & - \\
\hline
\end{tabular}

Sumber: Data Primer, Tahun 2018 (diolah)

Berdasarkan Tabel 4.2 dapat kita lihat bahwa penilaian prestasi kerja pada karyawan Rayon Ampenan dan Rayon Cakranegara di tahun 2017 menunjukkan kedua karyawan Rayon berada pada kompetensi 1 dan 2 atau dalam kategori Pencapaian Luar Biasa / Outstanding (OS) dan Melampaui Harapan / Exceeds Requirements (ER), yaitu pada Rayon Ampenan sama-sama berjumlah 10 orang. Sedangkan karyawan Rayon Cakranegara pada kompetensi 1 atau Pencapaian Luar Biasa / Outstanding (OS) terdapat jumlah karyawan yaitu sebanyak 8 orang, dan yang berada pada kompetensi 2 atau Melampaui Harapan / Exceeds Requirements (ER) sebanyak 12 orang. Dengan demikian walaupun kedua Rayon tersebut berada pada 2 kategori yang sama akan tetapi terdapat perbedaan jumlah masing-masing karyawan pada 2 kategori tersebut.

\section{Analisis dan Hasil Penelitian}

Pada bagian ini akan dijelaskan ada tidaknya perbedaan yang signifikan antara kinerja karyawan Rayon Ampenan dan Rayon Cakranegara dengan menggunakan analisis statistik yaitu uji Normalitas terhadap instrument yang diajukan sehingga instrument yang digunakan untuk mengumpulkan data adalah valid dan dapat dipercaya. Pengujian Hipotesis pada penelitian ini menggunakan independent sample t-test.

\section{Statistik Deskriptif}

Adapun data di atas merupakan hasil dari dilakukannya pengumpulan data untuk dapat memperoleh kesimpulan dalam melaksanakan penelitian, maka data yang telah diperoleh tersebut selanjutnya akan diolah lebih lanjut agar nilai yang telah diperoleh memiliki arti. Pengolahan data dalam suatu penelitian dilakukan untuk menemukan jawaban terhadap rumusan masalah yang diajukan sebelumnya. Proses analisis data dilakukan menggunakan data yang terkumpul dan diolah dengan menggunakan statistik program software computer yaitu Statistical Product and Service Solution (SPSS) Seri 23.0 yang terlihat pada Tabel 4.5 dibawah ini:

Tabel 4.3 Deskriptif Statistik

\begin{tabular}{|c|c|c|}
\hline \multicolumn{3}{|c|}{ Descriptives } \\
\hline & Rayon Ampenan & Rayon Cakranegara \\
\hline Valid & 20 & 20 \\
\hline Missing & 0 & 0 \\
\hline Mean & 109.7650 & 108.9250 \\
\hline Median & 110.0750 & 107.6250 \\
\hline Std. Deviation & 4.75337 & 3.88135 \\
\hline Minimum & 103.30 & 104.20 \\
\hline Maximum & 125.60 & 117.25 \\
\hline
\end{tabular}


Pada Tabel 4.3 di atas dapat dilihat bahwa Penilaian Prestasi Kerja Karyawan pada Rayon Ampenan dan Rayon Cakranegara adalah merupakan gambaran pencapaian kinerja dari masing-masing individu tersebut memiliki nilai rata-rata pada karyawan Rayon Ampenan sebesar 109,7 nilai maksimum 125,60 dan minimum 103,30 serta nilai standar deviasi 4,75, dengan nilai tengah sebanyak 110,07. Sedangkan Penilaian Prestasi Kerja pada karyawan Cakranegara memiliki nilai rata-rata sebesar 108,9 nilai maksimum 117,25 , nilai minimum 104,20 dan nilai standar deviasi 3,88 serta nilai tengahnya sebesar 107,6 .

\section{Hasil Uji Normalitas}

Uji normalitas yang digunakan dalam penelitian ini adalah uji KolmogorovSmirnov. Kolmogorov-Smirnov digunakan untuk menguji hipotesis komparatif dua sampel independen dengan data rasio dan disusun dalam tabel distribusi frekuensi kumulatif. Penelitian ini menggunakan tingkat kepercayaan sebesar 95\%. Analisis didasarkan pada nilai probabilitas (Sig) yang dibandingkan dengan derajat kebebasan $\alpha=$ 0,05. Adapun kriteria pengambilan keputusan dalam uji Kolmogorov-Smirnov adalah sebagai berikut:

a. Jika signifikansi $>0,05$ maka data tersebut berdistribusi normal.

b. Jika signifikansi $<0,05$ maka data tersebut tidak berdistribusi normal.

Tabel 4.4. Hasil Uji Normalitas Menggunakan Kolmogorov-Smirnov

\begin{tabular}{|l|l|l|l|}
\hline \multicolumn{4}{|c|}{ Tests of Normality } \\
\hline \multirow{4}{*}{ Rayon Ampenan } & \multicolumn{3}{|c|}{ Kolmogorov-Smirnov } \\
\cline { 2 - 4 } & Statistic & df & Sig. \\
\hline Rayon Cakranegara & .184 & 20 & .074 \\
\hline a. Lilliefors Significance Correction & .189 & 20 & .059 \\
\hline
\end{tabular}

Berdasarkan Tabel 4.4 di atas diketahui bahwa semua data berdistribusi normal karena nilai Sig $>0,05$.

\section{Hasil Uji Homogenitas}

Dalam statistik Uji Homogenitas digunakan untuk mengetahui apakah varian dari beberapa populasi sama atau tidak. Teknik yang digunakan untuk menguji homogenitas adalah program SPSS 23.0 for windows: test of homogeneity of variances dengan uji levene statistic. Adapun dasar pengambilan keputusan dalam uji homogenitas adalah:

1. Jika nilai signifikansi atau probabilitas $(\mathrm{p})>0,05$, maka dikatakan bahwa varian dari dua atau lebih kelompok populasi data adalah sama.

2. Jika nilai signifikansi atau probabilitas $(\mathrm{p})<0,05$, maka dikatakan bahwa varian dari dua atau lebih kelompok populasi data adalah tidak sama.

Tabel 4.5. Hasil Uji Homogenitas

\begin{tabular}{|c|c|r|r|r|c|}
\hline \multicolumn{7}{|c|}{ Test of Homogeneity of Variances } \\
\hline & $\begin{array}{c}\text { Levene } \\
\text { Statistic }\end{array}$ & df1 & df2 & Sig. \\
\hline Nilai KPI & Based on Mean & .002 & 1 & 38 & .968 \\
\hline
\end{tabular}


Berdasarkan hasil output SPSS dengan analisis Levene's statistic diatas diketahui bahwa nilai signifikansi, $\mathrm{p}=0,968>0,05$ artinya bahwa kedua objek memiliki varians yang sama, dengan begitu maka sampel dari penelitian berasal dari populasi yang sama.

\section{Hasil Pengujian Hipotesis menggunakan Independent Sample t-test}

Pengujian hipotesis independent sample t-test merupakan uji beda yang digunakan untuk mengetahui ada atau tidaknya perbedaan yang signifikan rata-rata antara dua kelompok sampel yang tidak berhubungan. Variabel yang diteliti dimaksudkan untuk membuktikan apakah variabel yang digunakan yaitu Key Performance Indikator (KPI) dengan 5 perspektif indikator pada kinerja Karyawan Ampenan dan Karyawan Rayon Cakranegara yang diakui tidak memiliki perbedaan yang signifikan. Seperti yang telah diungkapkan dalam perumusan hipotesis pada Bab II.

Untuk melakukan pembuktian terhadap hipotesis tersebut, berikut ini disajikan ringkasan hasil perhitungan data melalui SPSS 23.0 For Windows.

Tabel 4.6. Hasil Pengujian Hipotesis Independent Sample t-test

\begin{tabular}{|c|l|c|c|c|c|c|c|c|}
\hline & \multicolumn{1}{|c|}{ Rayon } & $\mathrm{N}$ & Mean & thitung & tabel & $\mathrm{df}$ & Sig. & Keterangan \\
\hline \multirow{2}{*}{$\begin{array}{c}\text { Nilai } \\
\text { KPI }\end{array}$} & $\begin{array}{l}\text { Rayon } \\
\text { Kmpenan }\end{array}$ & 20 & 109.7650 & .612 & 2.024 & 38 & .544 & Signifikan \\
\cline { 2 - 8 } & $\begin{array}{l}\text { Rayon } \\
\text { Cakranegara }\end{array}$ & 20 & 108.9250 & & & & & \\
\hline
\end{tabular}

\section{Pengujian Hipotesis}

Pengujian ini dilakukan untuk mengetahui apakah tidak terdapat perbedaan kinerja yang signifikan antara karyawan yang ada di Rayon Ampenan dan Rayon Cakranegara. Adapun langkah-langkah pengujian hipotesis adalah sebagai berikut:

a. Perumusan hipotesis:

1. Jika probabilitas (p) / sig. $<0,05$ atau jika thitung $>t_{\text {tabel }}$ maka terdapat perbedaan yang signifikan antara kinerja karyawan Rayon Ampenan dan Rayon Cakranegara (Ho ditolak).

2. Jika probabilitas (p) / sig. $>0,05$ atau jika thitung $<$ tabel maka tidak terdapat perbedaan yang signifikan antara kinerja karyawan Rayon Ampenan dan Rayon Cakranegara (Ho diterima).

b. Menentukan taraf signifikansi $(\alpha)$

Pengujian menggunakan uji dua sisi dengan tingkat signifikansi $(\alpha)=5 \%$. Tingkat signifikansi dalam hal ini berarti kita mengambil risiko salah dalam mengambil keputusan untuk menolak hipotesis yang sebanyak-banyaknya $0,05(0,025$ untuk masing-masing sisi).

c. Menentukan thitung

Dari tabel 4.6 didapat nilai t hitung sebesar 0.612 .

d. Menentukan $t$ tabel

Tabel distribusi t dicari pada $\alpha=5 \%: 2=2,5 \%$ (uji 2 sisi) dengan derajat kebebasan (df) yang diperoleh, terdapat nilai df pada tabel 4.10 sebesar 38. Dengan pengujian 2 sisi (signifikansi $=0,025$ ) hasil yang diperoleh untuk t tabel sebesar 2.024.

e. Hasil Pengujian

Berdasarkan Uji hipotesis yang telah dilakukan dengan menggunakan uji-t sampel independen (independent sample t-test). Dari hasil analisis data menggunakan SPSS, 
menunjukkan bahwa nilai $\mathrm{p}=0,544$. Karena $\mathrm{p}>0,05$ atau $0,544>0,05$ atau nilai $\mathrm{t}$ hitung $(0.612)<\mathrm{t}$ tabel $(2.024)$ maka hipotesis yang menyatakan bahwa tidak terdapat perbedaan yang signifikan diterima (Ho diterima), sehingga dapat dikatakan bahwa tidak terdapat adanya perbedaan yang signifikan pada kinerja karyawan antara Rayon Ampenan dan Rayon Cakranegara. Nilai mean kelompok karyawan Rayon Ampenan sebesar 109,7 menunjukkan angka yang tidak jauh berbeda dari nilai mean kelompok karyawan Rayon Cakranegara yang sebesar 108,9 atau memiliki selisih nilai yang sedikit. Sehingga diperoleh kesimpulan bahwa kinerja karyawan pada Rayon Ampenan tidak menunjukkan adanya perbedaan nilai rata-rata yang jauh lebih tinggi dari pada karyawan Rayon Cakranegara sehingga hal tersebut juga menunjukkan tidak terdapat adanya perbedaan kinerja yang signifikan.

\section{Pembahasan}

Hasil dari analisis data didapatkan nilai $\mathrm{p}=0,544$ atau $\mathrm{p}>0,05$ atau $\mathrm{t}$ hitung $(0.612)<\mathrm{t}$ tabel $(2.024)$ berdasarkan hasil tersebut, maka hipotesis yang diajukan dalam penelitian ini didukung oleh data yang diperoleh, atau dengan kata lain hipotesis penelitian yang menyatakan bahwa tidak ada perbedaan kinerja yang signifikan antara kinerja karyawan Rayon Ampenan dan Rayon Cakranegara dapat diterima. Nilai mean empiris yang diperoleh oleh masing-masing kelompok karyawan juga menunjukkan tidak adanya perbedaan yang signifikan. Mean kelompok karyawan Rayon Ampenan sebesar 109,7 tidak menunjukkan angka yang jauh berbeda dari nilai mean kelompok karyawan Rayon Cakranegara yang sebesar 108,9. Hasil angka dari mean tersebut menunjukkan bahwa tidak adanya perbedaan secara signifikan pada tingkat kinerja karyawan Rayon Ampenan dan karyawan Rayon Cakranegara.

Hasil analisis penelitian yang terlihat pada kinerja karyawan yang telah dilakukan di Rayon Ampenan dan Rayon Cakranegara dengan seluruh sampel sebanyak 40 karyawan yang terdiri dari 20 karyawan dari masing-masing Rayon yang menjadi objek penelitian ini. Dalam hal penelitian terhadap kinerja karyawan tersebut, dilaksanakan dengan menggunakan instrument Key performance indicators (KPI) yang telah dijadikan sebagai indikator dalam menilai kinerja karyawan secara individu pada semua level jabatan, maupun juga pada tingkat unit Rayon dalam lingkup perusahaan PT. PLN (Persero) diseluruh Indonesia, termasuk PT. PLN (Persero) Wilayah NTB di Area Mataram yang membawahi Rayon Ampenan dan Rayon Cakranegara.

Bertitik tolak dari hal itu, maka dapat diperoleh gambaran hasil penelitian secara menyeluruh dan mendalam tentang kinerja karyawan, dengan analisis berdasarkan pada beberapa aspek pendekatan dengan tetap berpedoman menggunakan KPI yaitu:

a. Pendekatan melalui analisis pencapaian kinerja karyawan berdasarkan posisi penugasan atau jabatan.

Pendekatan ini dimaksudkan untuk mengukur seberapa besar pencapaian kinerja setiap karyawan secara individu berdasarkan posisi penugasan sesuai dengan masing-masing jabatannya dalam rangka pencapaian kinerja unit Rayon berdasarkan indikator KPI.

b. Pendekatan melalui analisis pencapaian kinerja untuk mengukur tingkat kompetensi karyawan pada semua posisi jabatan atau posisi penugasan.

Pendekatan ini dimaksudkan untuk mengukur hasil pencapaian kinerja karyawan, sehingga dengan demikian akan dapat ditentukan kategori tingkat kompetensi yang dimilikinya.

c. Pendekatan melalui analisis tingkat persentase pencapaian kinerja karyawan berdasarkan masing-masing perspektif indikator dalam KPI. 
Pendekatan ini bertujuan untuk mengukur seberapa besar persentase kinerja karyawan berdasarkan setiap perspektif indikator dalam KPI dalam rangka pencapaian kinerja unit Rayon tempat karyawan bertugas.

Berdasarkan pendekatan penilaian kinerja karyawan di atas, dapat diketahui bahwa penilaian prestasi kerja pada karyawan Rayon Ampenan dan Rayon Cakranegara di tahun 2017 menunjukkan bahwa pada ke-2 (kedua) karyawan Rayon rata-rata berada pada kompetensi 1 dan 2 atau dalam kategori Pencapaian Luar Biasa / Outstanding (OS) dan Melampaui Harapan / Exceeds Requirements (ER), dimana pada Rayon Ampenan sama-sama berjumlah 10 orang. Sedangkan karyawan Rayon Cakranegara pada kompetensi 1 atau Pencapaian Luar Biasa / Outstanding (OS) terdapat jumlah karyawan yaitu sebanyak 8 orang, dan yang berada pada kompetensi 2 atau Melampaui Harapan / Exceeds Requirements (ER) sebanyak 12 orang. Dengan demikian walaupun kedua Rayon tersebut berada pada 2 kategori yang sama akan tetapi terdapat perbedaan jumlah masing-masing karyawan pada 2 kategori tersebut. Dan tingkat persentase kontribusi karyawan pada masing-masing unit rayon berdasarkan setiap perspektif indikator utama/ KPI terhadap pencapaian kinerja rayon tempat karyawan bertugas menunjukkan pencapaian yang Melampaui Harapan.

Meskipun secara individu kinerja karyawannya melampaui harapan dan berada pada pencapaian luar biasa, namun apabila dikaitkan dengan kinerja Rayon maka belum terhitung mencapai target kerja yang telah ditetapkan oleh masing-masing unit Rayon, karena ada beberapa sub indikator yang menunjukkan adanya target yang belum tercapai di unit rayon tersebut, seperti yang dijelaskan pada latar belakang Bab I, tentang pencapaian KPI Rayon tahun 2017, dimana ke-2 (kedua) Rayon tersebut memiliki tingkat pencapaian nilai kinerja yang berbeda.

Artinya bahwa pencapaian kinerja yang baik ataupun sangat baik pada individu karyawan belum tentu menunjukkan pencapaian kinerja yang baik ataupun sangat baik pada tingkat unit rayon. Hal tersebut disebabkan oleh karena adanya beberapa faktor di luar kendali karyawan sehingga terjadi kendala dalam mencapai nilai kinerja yang maksimal, diantaranya yaitu:

1. Indikator Rasio Elektrifikasi

Pada Rayon Ampenan Rasio Elektrifikasi dapat memenuhi target, sedangkan Rayon Cakranegara tidak dapat memenuhi target yang ditetapkan, karena wilayah kerja Rayon Cakranegara mencakup Wilayah Kabupaten Lombok Barat. Perlu diketahui bahwa pada beberapa tempat di Kabupaten Lombok Barat pola pemukimannya tersebar karena faktor geografis, sehingga masih terdapat sebagian masyarakat belum dapat dilayani listrik PLN.

2. Penjualan Tenaga Listrik Non Subsidi

Pada Rayon Ampenan penjualan tenaga listrik non subsidi dapat memenuhi target, tetapi Rayon Cakranegara tidak dapat memenuhi target dalam hal penjualan tenaga listrik non subsidi untuk pelanggan rumah tangga. Hal itu disebabkan karena berkaitan dengan pola pemukiman penduduk yang tersebar sehingga tidak dapat dilayani listrik PLN. Namun untuk pelanggan non rumah tangga Rayon Cakranegara dapat memenuhi target karena diperuntukkan bagi kegiatan industri, perkantoran dan pusat perdagangan.

3. Gangguan Penyulang

Rayon Ampenan tidak dapat memenuhi target karena pada saat musim penghujan atau saat terjadi angin besar banyak terjadi pepohonan yang tumbang, karena di beberapa tempat Wilayah Rayon Ampenan masih terdapat pohon-pohon yang berumur tua. Selain itu terdapat adanya pengambilan listrik secara illegal. 
4. Indikator Kehandalan Jaringan

SAIDI dan SAIFI:

Rayon Ampenan dan Rayon Cakranegara belum dapat mencapai target yang ditetapkan, yaitu meminimalkan adanya gangguan pemadaman listrik, disebabkan adanya dampak dari kegiatan perubahan jaringan listrik yaitu adanya pembangunan pembangkit (PLTU /Pembangkit Listrik Tenaga Uap) yang berlokasi di Jeranjang Lombok Barat yang bertujuan untuk suplai tenaga listrik ke lokasi BIL (Bandara Internasional Lombok), dan juga disebabkan adanya pergantian mesin baru pada PLTD (Pembangkit Listrik Tenaga Diesel) Tanjung Karang Ampenan.

\section{KESIMPULAN DAN SARAN}

\section{Kesimpulan}

Berdasarkan hasil penelitian, dapat disimpulkan bahwa:

Hasil analisis menunjukkan nilai uji-t sebesar 612 dengan nilai $p=0,544$ atau $p>$ 0,05 , sehingga diperoleh kesimpulan bahwa tidak ada perbedaan kinerja yang signifikan antara kinerja karyawan Rayon Ampenan dan Rayon Cakranegara. Dimana dari hasil penelitian terhadap sampel 40 karyawan yang masing-masing terdiri dari 20 orang pada karyawan Rayon Ampenan dan Rayon Cakranegara, berdasarkan posisi penugasannya atau jabatannya masing-masing, secara keseluruhan nilai Key Performance Indicators (KPI) rata-rata menunjukkan tingkat pencapaian kinerja masing-masing karyawan pada ke-2 (kedua) rayon tersebut berada pada level yang sama yaitu sudah mencapai Pencapaian Luar Biasa/Kompetensi 1 dan Melampaui Harapan/Kompetensi 2. Dan ratarata kontribusi kinerja pada ke-2 (kedua) karyawan rayon telah mencapai Exceeds Requirements (ER). Apabila dibandingkan nilai rata-rata tingkat pencapaian kinerja masing-masing karyawan pada Rayon Ampenan dan Rayon Cakranegara tidak menunjukkan adanya perbedaan yang signifikan, dimana angka pencapaian kinerja masing-masing karyawan pada Rayon Ampenan rata-rata mencapai angka sebesar 109,7, dan Rayon Cakranegara mencapai angka yaitu rata-rata sebesar 108,9.

\section{Saran}

1. Untuk meningkatkan kinerja karyawan di Rayon Ampenan khususnya pada bagian teknik dengan jabatan staf/Assisten Operator Operasi distribusi perlu ditingkatkan keterampilan dan pengetahuan operator melalui pelaksanaan pendidikan dan pelatihan sesuai kompetensi yang dibutuhkan. Secara rutin dilaksanakan berbagi pengetahuan (Knowledge Sharing).

2. Kemudian untuk meningkatkan kinerja karyawan di Rayon Cakranegara dengan cara meningkatkan kualitas SDM terutama di bagian Transaksi Energi Listrik (TEL) dengan jabatan staf/Engineer Operasi Pemeliharaan Pembangkit, untuk mempertahankan performa kerja karyawannya sebaiknya perusahaan perlu meningkatkan kemampuan mesin yang sudah ada dan untuk meningkatkan pelayanan daya listrik untuk konsumen.

3. Untuk penelitian selanjutnya diharapkan adanya penelitian dalam hal analisis program pelatihan dan pengembangan sumber daya manusia, untuk karyawan PLN antar Rayon dalam rangka peningkatan kinerja. 


\section{REFERENSI}

Arikunto, Suharsimi. 2006. Prosedur Penelitian, Suatu Pendekatan Praktik. Jakarta: Rineka Cipta.

Budi, Triton P. 2006. SPSS 13.0 Terapan; Riset Statistik Parametrik. Yogyakarta: C.V Andi Offset.

Damayanti, Vinny dan Marliana. 2007. Analisa Perbandingan Kinerja Karyawan di Restoran yang Menerapkan Iso 9001:2000 Dan Restoran - Restoran yang Tidak Menerapkan Iso 9001:2000 Di Surabaya. Fakultas Ekonomi Universitas Kristen Petra Surabaya.

Dessler, Gary. 2009. Manajemen Sumber Daya Manusia DM Buku1. Jakarta: PT. Indeks.

2009. Manajemen Sumber Daya Manusia DM Buku1. Jakarta: PT. Indeks.

Fauziah. 2016. Analisis Perbandingan Kinerja Pegawai di Kantor Camat Kabupaten Rokan Hulu (Studi Kasus Di Kantor Camat Tambusai Dan Kantor Camat Rambah). Program Studi Manajemen Fakultas Ekonomi Universitas Pasir Pengaraian.

Mangkunegara, A.P. 2015. Manajemen Sumber Daya Manusia Perusahaan. Bandung: PT. Remaja Rosdakarya.

Moheriono. 2012. Pengukuran Kinerja Berbasis Kompetensi. Jakarta: PT. Raja Grafindo Persada.

2014. Pengukuran Kinerja Berbasis Kompetensi. Jakarta: PT. Raja Grafindo Persada.

Mudiartha, Utama dan I Wayan. 2001. Manajemen Sumber Daya Manusia. Denpasar UPT: Universitas Udayana.

Rahayu, Sri. 2005. SPSS Versi 12.0 Dalam Riset Pemasaran. Bandung: CV. Alfabeta

Rivai, Veithzal, et al. 2008. Evaluasi Kinerja. Bandung: Refika Utama.

Sugiyono. 2010. Metode Penelitian Kuantitatif Kualitatif dan R\&B. Bandung: Alfabeta.

— 2012. Metode Penelitian Bisnis. Bandung: Alfabeta.

_. 2017. Metode Penelitian Bisnis. Bandung: Alfabeta.

Usman, Husaini dan Akbar, Purnomo S. 2008. Metodologi Penelitian Sosial. Jakarta: Bumi Aksara

Kementrian BUMN Surat keputusan Nomor S-08/S.MBU/2013 Pedoman Penentuan Key Performance Indicators (KPI) 